\title{
PENGARUH FRAKSI AKTIF AGLAIA HARMSIANA PERKINS (MELIACEAE) TERHADAP FISIOLOGI LARVA SPODOPTERA LITURA (F.) (LEPIDOPTERA: NOCTUIDAE)
}

\author{
Eka Candra Lina ${ }^{1}$, Djoko Prijono², Dadang ${ }^{2}$
}

\begin{abstract}
The effect of active fraction Aglalia harmsiana Perkins (Meliaceae) to physiology of Spodoptera litura (F.) (Lepidoptera : Noctuidae) larvae. This study was conducted to evaluate the physiological interferences in the soybean armyworm Spodoptera litura caused by active fractions of Aglaia harmsiana seed extract. The activity of the test materials was assessed by dietary preparation and topical application method. Repeated fractionations of $A$. harmsiana extract by chromatographic methods yielded two active fractions, designated as fraction 2-7 (0.0184\%) and 2-8 (0.3773\%). The results showed that fraction 2-8 had strong insecticidal activity against $S$. litura larvae, with $\mathrm{LC}_{50}$ by topical application and dietary preparation were $0.49 \%$ and $0.0044 \%$, respectively. A sublethal treatment with the active fraction $\left(\mathrm{LC}_{25}\right)$ reduced the relative growth rate, efficiency of conversion of ingested food, and efficiency of conversion of digested food by 52.9\%, $42.9 \%$, 49.6\% with topical application and $66.7 \%, 50 \%, 63.8 \%$ with dietary preparation method. The treatments with that fraction at $\mathrm{LC}_{10}$ and $\mathrm{LC}_{25}$ to the fourth instars reduced the activity of invertase enzyme by $34 \%$ and $47 \%$, but increased the activity of trehalase by $6.2 \%$ and $12.5 \%$ as compared with controls.
\end{abstract}

Key words : A. harmsiana, S. litura, botanical insecticide, metabolic enzymes

\section{PENDAHULUAN}

Dampak negatif insektisida sintetik, di antaranya resistensi dan resurjensi hama sasaran, terbunuhnya musuh alami dan organisme bukan sasaran lainnya, pencemaran lingkungan serta bahaya residu pada hasil panen (Metcalf 1982; Kuroki 1998) telah mendorong orang untuk mencari alternatif yang lebih aman. Bahan insektisida dari tumbuhan (insektisida botani) menjadi pilihan karena memiliki dampak negatif yang relatif lebih lunak dibandingkan dengan insektisida sintetik, yaitu lebih mudah terurai di lingkungan dan umumnya cukup aman terhadap musuh alami hama (Isman 1995; Schmutterer 1997).

Anggota famili Meliaceae, di antaranya genus Aglaia, telah dikenal sebagai sumber insektisida botani yang potensial. Salah satu spesies Aglaia yang menjanjikan ialah A. harmsiana. Hartati \& Prijono (1994) melaporkan bahwa ekstrak metanol biji A. harmsiana mempunyai efek antifeedant dan menghambat perkembangan larva Crocidolomia pavonana (F.) (Lepidoptera: Pyralidae). Fraksi aktif ekstrak biji $A$. harmsiana pada konsentrasi subletal juga menurunkan jumlah sel darah larva $C$. pavonana sebesar $47 \%$, sehingga menurunkan enkapsulasi telur dan larva parasitoid oleh inang yang diberi perlakuan fraksi tersebut (Dono et al. 1998). Wiyantono et al. (2001) menyebutkan bahwa perlakuan subletal secara kontak fraksi $\mathrm{CH}_{2} \mathrm{Cl}_{2}$ biji $A$. harmsiana pada $\mathrm{LD}_{25}$ menurunkan laju pertumbuhan, efisiensi konversi makanan dikonsumsi dan efisiensi konversi makanan dicerna larva instar ke-3 C. pavonana.

Senyawa aktif yang berhasil diisolasi dari daun A. harmsiana termasuk golongan benzofuran turunan dari rokaglamida, yang memiliki efek antifeedant, penghambat perkembangan, dan insektisida. Tujuh turunan rokaglamida yang berhasil diisolasi tersebut memiliki aktivitas insektisida terhadap Spodoptera littoralis (Boisduval) (Lepidoptera: Noctuidae) dengan LC $_{50}$ antara 0,8 dan 19,7 ppm (Nugroho et al. 1997).

Sampai sekarang landasan fisiologi yang dapat digunakan untuk menjelaskan berbagai pengaruh dari ekstrak A. harmsiana di atas belum diketahui dengan pasti. Sebagai tahap awal untuk mengungkapkan hal tersebut, terutama yang terkait dengan efek antifeedant dan penurunan efisiensi asimilasi makanan, perlu dilakukan percobaan untuk mengetahui pengaruh sediaan $A$. harmsiana terhadap aktivitas enzim metabolik. Selain itu, pemisahan komponen aktif juga perlu dilakukan.

Penelitian ini bertujuan menguji pengaruh fraksi aktif ekstrak biji $A$. harmsiana terhadap mortalitas dan pertumbuhan larva Spodoptera litura pada pakan buatan serta terhadap aktivitas enzim invertase dan trehalase.

\footnotetext{
${ }^{1}$ Dosen Jurusan Hama dan Penyakit Tumbuhan, Fakultas Pertanian, Universitas Andalas, Kampus Limau Manis, Padang

${ }^{2}$ Dosen Departemen Proteksi Tanaman, Fakultas Pertanian, Institut Pertanian Bogor, Jl. Kamper Kampus IPB Darmaga, Bogor
} 


\section{METODE PENELITIAN}

Penelitian dilaksanakan di Laboratorium Fisiologi dan Toksikologi Serangga, Departemen Hama dan Penyakit Tumbuhan (HPT), Institut Pertanian Bogor (IPB), dari Januari 2002 sampai Desember 2003.

Pemeliharaan Serangga Uji. Larva $S$. litura diperbanyak di Laboratorium Fisiologi dan Toksikologi Serangga, Departemen HPT-IPB. Larva diberi pakan buatan dalam wadah plastik $(13 \mathrm{~cm}$ x 11 $\mathrm{cm}$ x $5 \mathrm{~cm}$ ) yang bagian atasnya berjendela kasa sampai larva mencapai instar ke-2. Setelah menjadi instar ke-3, larva dipindahkan ke tabung plastik (diameter $4 \mathrm{~cm}$, tinggi $4,5 \mathrm{~cm}$ ) yang telah diisi pakan buatan. Pakan buatan yang berbahan dasar kacang merah dibuat berdasarkan resep yang dikemukakan oleh King \& Hartley (1985).

Menjelang pembentukan pupa, ke dalam tabung plastik dimasukkan serbuk gergaji steril sebagai tempat berpupa. Pupa yang terbentuk dikeluarkan dari kokon kemudian dipindahkan ke dalam kurungan plastik-kasa berbingkai kayu $(40 \mathrm{~cm}$ x $40 \mathrm{~cm}$ x 40 $\mathrm{cm})$. Imago yang muncul diberi makan larutan madu (10\%) yang diserapkan pada kapas. Dua hari setelah kemunculan imago, ke dalam kurungan dimasukkan daun kedelai yang ditempatkan dalam botol film berisi air sebagai tempat peletakan telur. Telur yang menempel di permukaan daun dipindahkan ke cawan petri (diameter $15 \mathrm{~cm}$ ) sampai menetas. Larva instar ke-2 yang diperoleh digunakan untuk perlakuan dan perbanyakan selanjutnya.

Ekstraksi dan Fraksinasi. Biji kering A. harmsiana yang diperoleh dari Kebun Raya Bogor dihaluskan dengan blender dan diayak dengan pengayak bermata $0,5 \mathrm{~mm}$. Serbuk yang diperoleh diekstrak dengan metanol $(1: 10 \mathrm{w} / \mathrm{v})$ dalam labu erlenmeyer dan dikocok dengan pengocok magnetik sekurangkurangnya 24 jam. Ekstrak disaring menggunakan corong Büchner yang dialasi kertas saring Whatman No. 41. Pelarut diuapkan dengan rotary evaporator pada suhu $50{ }^{\circ} \mathrm{C}$ dan tekanan 337-600 mmHg.

Ekstrak yang diperoleh dipartisi dalam campuran heksana dan metanol 95\%, kemudian fraksi yang aktif dipartisi dalam campuran etil asetat dan air. Fraksi yang aktif dipisahkan lebih lanjut dengan teknik kromatografi vakum cair (KVC) seperti yang dikemukakan oleh Coll \& Bowden (1986). Pelarut yang digunakan adalah heksana, diklorometana, dan diklorometana:isopropanol (10:1). Fraksi yang aktif dipisahkan lebih lanjut pada kolom kromatografi dengan penjerap Silika Gel 60 (0,040-0,063 mm) dan eluen diklorometana:isopropanol (19:1). Fraksi yang diperoleh diperiksa kehomogenannya dengan kromatografi lapisan tipis (KLT). Fraksi pada pelat KLT diperiksa menggunakan lampu ultraviolet pada $\lambda 254 \mathrm{~nm}$. Setiap fraksi diuji aktivitasnya terhadap larva $S$. litura dengan cara seperti yang diuraikan pada Percobaan 1. Fraksi yang aktif dimurnikan lebih lanjut dengan kolom kromatografi dengan penjerap Silika Gel $60 \quad(0,040-0,063 \mathrm{~mm})$ dan eluen diklorometana:isopropanol (39:1). Fraksi aktif diperiksa kemurniannya dengan kromatografi cair kinerja tinggi (KCKT), dengan kolom C18 dan eluen metanol:air (7:3) kemudian dideteksi dengan sinar ultraviolet pada $\lambda 254 \mathrm{~nm}$.

\section{Percobaan 1. Toksisitas Fraksi Aktif Biji A. harmsiana terhadap Larva S. litura}

Pengujian menggunakan metode pencampuran bahan uji pada makanan buatan. Setiap tahap ekstraksi diikuti dengan uji hayati untuk menentukan aktivitas fraksi yang diperoleh, dan fraksi aktif digunakan sampai tahap akhir penelitian. Pengujian pada tahap pemantauan dilakukan pada konsentrasi $0,25-0,5 \%$, pada tahap partisi dilakukan pengujian untuk fase polar 0,25 dan $0,5 \%$ dan untuk fase nonpolar 0,01\%, 0,05\% dan 0,1\%. Fraksi KVC diuji lebih lanjut pada konsentrasi $0,01 \%$ dan 0,05\%. Fraksi yang aktif dipisahkan dengan kromatografi kolom dengan penjerap Silika Gel 60 (0,040-0,063) dengan eluen diklorometana:isopropanol (19:1) kemudian setiap fraksi diuji pada 0,01\%. Fraksi yang aktif dimurnikan lebih lanjut dengan kromatografi kolom dengan penjerap yang sama dan eluen diklorometana:isopropanol (39:1). Setiap fraksi yang diperoleh diuji pada konsentrasi 0,005\% terhadap larva instar ke-2 (20 ekor/fraksi).

Fraksi aktif yang diperoleh pada tahap akhir diuji lebih lanjut terhadap larva $S$. litura pada beberapa taraf konsentrasi yang diharapkan dapat menyebabkan kematian serangga uji antara $0 \%$ dan 100\%. Untuk setiap taraf konsentrasi digunakan 40 ekor larva instar ke-2 untuk metode pencampuran dengan pakan buatan dan 30 ekor larva instar ke-3 untuk metode kontak topikal. Pengujian dengan metode pencampuran bahan uji pada pakan buatan dilakukan dengan mencampurkan ekstrak (pelarut 
aseton) dengan pakan buatan. Aseton diuapkan dengan rotavapor kemudian ke dalam pakan ditambahkan akuades sebanyak tiga kali bobot pakan. Pakan dikocok dengan vorteks kemudian ditimbang kembali untuk mengoreksi konsentrasi ekstrak yang digunakan. Larva uji diberi pakan beperlakuan selama 7 hari. Pengujian dengan metode kontak topikal dilakukan dengan melarutkan ekstrak dalam aseton, kemudian $1 \mu \mathrm{l}$ larutan ekstrak diteteskan pada bagian dorsal toraks larva instar ke-3 menggunakan microapplicator. Larva diberi pakan tanpa perlakuan selama 2 haris. Mortalitas larva diamati dan dicatat setiap hari. Hubungan antara konsentrasi bahan uji dan tingkat kematian serangga uji pada kedua metode perlakuan diolah dengan analisis probit (Finney 1971).

\section{Percobaan 2. Pengaruh Fraksi Aktif Biji A. harmsiana terhadap Asimilasi Makanan oleh Larva S. litura}

Fraksi aktif pada $\mathrm{LC}_{10}$ dan $\mathrm{LC}_{25}$ diuji dengan metode kontak topikal (topical application) dan metode pencampuran pada pakan buatan terhadap larva S. litura instar ke-3 untuk mengetahui pengaruh ekstrak terhadap efisiensi asimilasi makanan. Cara perlakuan dengan metode pencampuran pada pakan buatan sama seperti pada Percobaan 1. Pengujian dengan metode kontak topikal mengikuti prosedur yang dijelaskan oleh Wiyantono et al. (2001)

Data yang diperoleh digunakan untuk menentukan laju konsumsi (LK), laju konsumsi relatif (LKR), laju pertumbuhan (LP), laju pertumbuhan relatif (LPR), daya cerna (DC), efisiensi konversi makanan dikonsumsi (EMK), dan efisiensi konversi makanan dicerna (EMC) berdasarkan metode gravimetri (Waldbauer 1968). Data setiap parameter diolah dengan sidik ragam dan pembandingan nilai tengah antarperlakuan dilakukan dengan uji BNT (Steel \& Torrie 1980).

\section{Percobaan 3. Pengaruh Fraksi Aktif Biji A. harmsiana terhadap Aktivitas Enzim Invertase dan Trehalase Larva S. litura}

Aktivitas enzim diukur berdasarkan reaksi antara glukosa hasil hidrolisis substrat dengan pereaksi asam dinitrosalisilat (ADNS). Sebagai sumber enzim invertase dan trehalase digunakan homogenat larva. Homogenat berasal dari larva
S. litura instar ke-4 yang diberi pakan beperlakuan fraksi 2-8 ( $\mathrm{LC}_{10}$ dan $\left.\mathrm{LC}_{25}\right)$ selama \pm 12 jam. Lima ekor larva dengan bobot $64 \mathrm{mg}$ (SB $5 \mathrm{mg}$ ) dimasukkan ke dalam homogenizer gelas yang diletakkan di atas wadah berisi pecahan es, kemudian ditambahkan $2 \mathrm{ml}$ akuabides dan digerus. Selanjutnya homogenat disentrifus pada kecepatan 10.000 rpm selama 15 menit pada suhu $4{ }^{\circ} \mathrm{C}$. Supernatan yang diperoleh disimpan dalam freezer pada suhu $-74^{\circ} \mathrm{C}$ hingga saat digunakan.

Analisis aktivitas enzim mengikuti prosedur yang dilakukan Ishaaya et al. (1996). Campuran bahan untuk analisis aktivitas enzim invertase ialah $0,4 \mathrm{ml}$ sukrosa $4 \%, 0,4 \mathrm{ml} \mathrm{H}_{2} \mathrm{O}, 0,2 \mathrm{ml}$ homogenat, dan 0,4 $\mathrm{ml}$ buffer fosfat $0,2 \mathrm{M} \mathrm{pH} \mathrm{5,5.} \mathrm{Campuran}$ bahan tersebut juga digunakan untuk analisis aktivitas enzim trehalase kecuali sukrosa 4\% diganti dengan trehalosa $4 \%$. Setiap tabung yang berisi campuran bahan diinkubasi selama 60 menit pada suhu $37^{\circ} \mathrm{C}$. Setelah itu ditambahkan 1,6 ml pereaksi ADNS, kemudian dipanaskan selama 5 menit pada suhu $100{ }^{\circ} \mathrm{C}$. Lima menit kemudian campuran langsung didinginkan dalam air es, kemudian absorbansinya diukur pada panjang gelombang $550 \mathrm{~nm}$. Untuk penentuan kurva standar, glukosa pada beberapa konsentrasi langsung direaksikan dengan ADNS sehingga diperoleh hubungan antara konsentrasi glukosa dan absorbansi. Aktivitas enzim dinyatakan sebagai mg glukosa/mg protein.

Kandungan protein dalam sampel homogenat dikoreksi dengan kadar protein dalam sampel yang sama yang diukur menggunakan metode Lowry (Kresze 1998) dengan standar bovine serum albumin. Campuran bahan untuk analisis protein ialah $25 \mu \mathrm{l}$ homogenat, $575 \mu \mathrm{l}$ akuabides dan $3 \mathrm{ml}$ pereaksi tembaga-alkalin kemudian dikocok dengan vorteks dan dibiarkan selama 10 menit. Selanjutnya $0,15 \mathrm{ml}$ larutan Folin-Ciocalteau ditambahkan ke dalam setiap tabung, lalu dikocok lagi dan dibiarkan selama 30 menit. Absorbansi larutan diukur pada panjang gelombang $500 \mathrm{~nm}$.

\section{HASIL DAN PEMBAHASAN}

Fraksinasi Ekstrak. Ekstraksi serbuk biji A. harmsiana sebanyak $568 \mathrm{~g}$ dengan metanol menghasilkan ekstrak sebanyak 97,88 g (17,23\%). Hasil partisi ekstrak tersebut dalam pelarut heksana dan metanol 95\% menghasilkan fraksi metanol 78,03 g. Partisi fraksi metanol dalam etil asetat dan air menghasilkan fraksi etilasetat 11,13 g. Pemisahan 
fraksi etil asetat dengan KVC menghasilkan fraksi heksana 0,6414 g, fraksi diklorometana 1,1343 g, dan diklorometana:isopropanol (10:1) 0,32 g. Pemisahan fraksi terakhir dengan kolom kromatografi (penjerap Silika Gel $\left.60 \quad \mathrm{H} \quad \mathrm{F}_{254}\right)$ dan eluen diklorometana:isopropanol (19:1), serta pemeriksaan dengan KLT (Silica Gel $60 \mathrm{G}$ ), visualisasi UV $\lambda=254 \mathrm{~nm}$ ) menghasilkan tujuh fraksi (Tabel 1).

Fraksi 2 yang aktif dimurnikan lebih lanjut dengan kromatografi kolom dengan eluen diklorometana-isopropanol (39:1), dan dihasilkan
10 fraksi (Tabel 2). Fraksi 2-8 yang diketahui paling aktif diperiksa kemurniannya dengan KCKT. Fraksi 2-8 belum bisa dikatakan murni karena masih memiliki dua puncak utama yang belum terpisah dengan baik (Gambar 1B). Pada kromatogram, puncak fraksi 2-8 muncul lebih akhir dibandingkan rokaglamida (standar). Puncak rokaglamida muncul pada menit ke 6,25 sedangkan fraksi 2-8 muncul pada menit ke 13,29 dan 13,89 (Gambar 1C). Hal tersebut menunjukkan bahwa fraksi 2-8 lebih nonpolar dibandingkan dengan rokaglamida.

Tabel 1. Hasil fraksinasi ekstrak biji A. harmsiana dan aktivitas insektisidanya terhadap larva S. litura

\begin{tabular}{ccclr}
\hline Fraksi & $\begin{array}{c}\text { Hasil } \\
(\%)^{1)}\end{array}$ & $\begin{array}{c}\text { Eluen diklorometana- } \\
\text { isopropanol (19:1) }(\mathrm{ml})\end{array}$ & \multicolumn{1}{c}{$\mathrm{R}_{\mathrm{f}}$} & $\begin{array}{c}\text { Mortalitas larva } \\
\text { S. litura }(\%)\end{array}$ \\
\hline 1 & 0,020 & $0-650$ & $-(2)$ & 10 \\
2 & 0,134 & $651-770$ & 0,$75 ; 0,7 ; 0,63 ; 0,55 ; 0,48 ; 0,4$ & 100 \\
3 & 0,034 & $771-1180$ & 0,$73 ; 0,64 ; 0,57$ & 5 \\
4 & 0,015 & $1181-1280$ & 0,$63 ; 0,53$ & 0 \\
5 & 0,102 & $1281-1780$ & 0,$62 ; 0,48$ & 0 \\
6 & 0,074 & $1781-1905$ & 0,54 & 10 \\
7 & 0,217 & Metanol 200 ml & $-(2)$ & 10 \\
\hline
\end{tabular}

1) Bobot fraksi relatif terhadap bobot serbuk biji.

2) Tidak menghaslkan pemisahan fraksi pada pelat KLT.
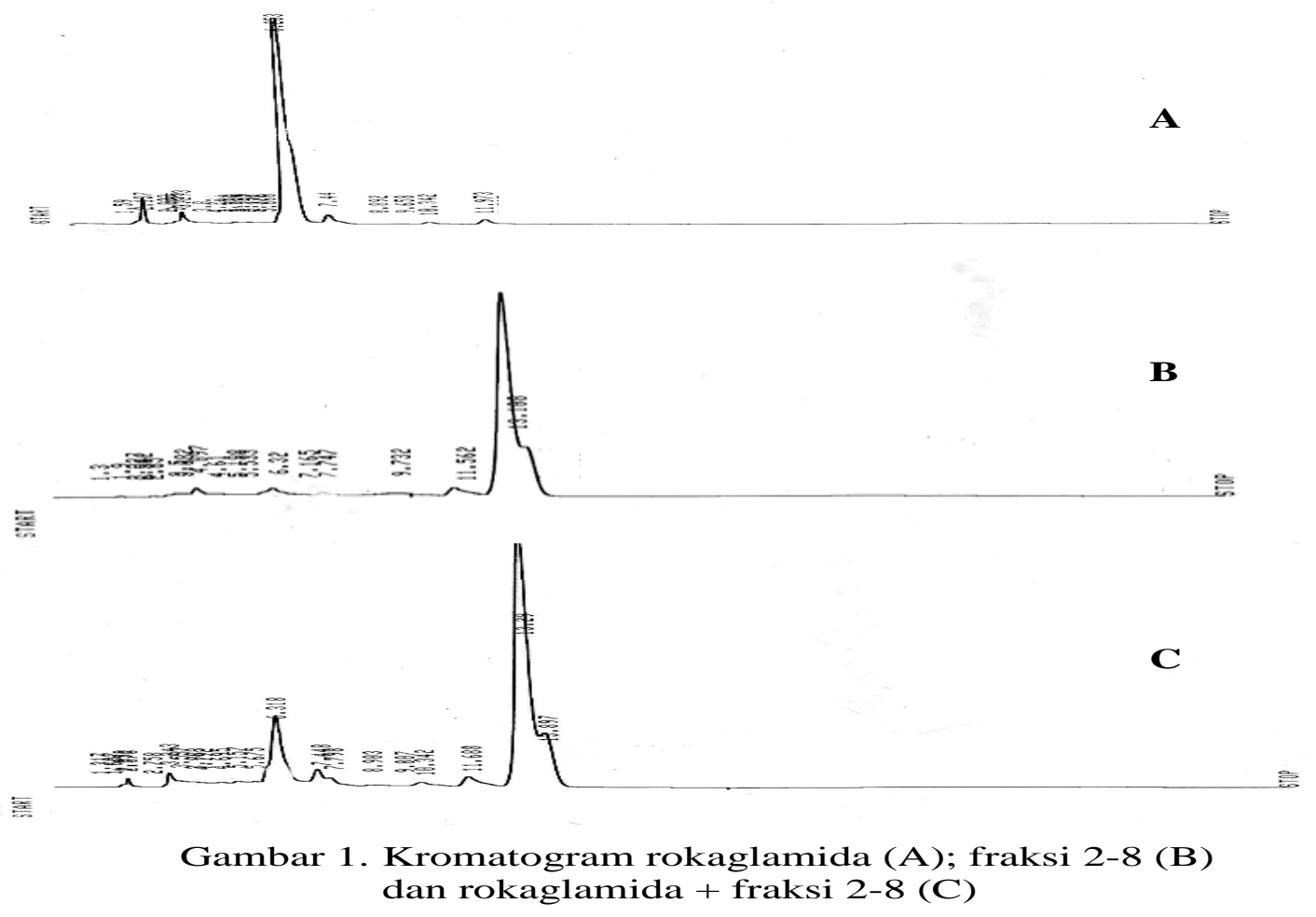
Toksisitas Ekstrak Biji A. harmsiana terhadap Larva S. Litura. Fraksi aktif biji A. harmsiana menunjukkan aktivitas insektisida yang kuat. Fraksi 2 pada hari ke-7 pengamatan menyebabkan kematian larva uji 100\%, kemudian diikuti oleh fraksi 5 dengan tingkat kematian 75\% (Tabel 1). Fraksi 2-8 hasil fraksinasi fraksi 2 menyebabkan kematian larva uji $100 \%$ pada hari ke-7 pengamatan, kemudian diikuti oleh fraksi 2-7 dan 2-9 yang menyebabkan kematian larva berturut-turut $80 \%$ dan $45 \%$ (Tabel 2).

Pada uji topikal, fraksi 2-8 yang diteteskan pada larva meresap melalui kutikula dan mengikuti aliran darah. Senyawa aktif fraksi bekerja dan mematikan larva uji tanpa melewati proses yang bisa mempengaruhi perilaku makan secara langsung. Selain itu kematian larva juga dapat disebabkan adanya sumbangan dari sifat antifeedant (penghambat aktivitas makan) yang dikandung fraksi 2-8. Pada pengamatan secara visual tampak larva uji makan lebih sedikit pakan beperlakuan jika dibandingkan dengan pada pakan tanpa perlakuan. Jadi, kematian larva uji dapat disebabkan oleh adanya toksisitas intrinsik dan penghambatan aktivitas makan. Hal ini sesuai dengan hasil penelitian Dono \& Prijono (1998) yang menunjukkan bahwa fraksi $\mathrm{E}$ ekstrak biji A. harmsiana menyebabkan kematian larva C. pavonana melalui sifat toksisitas intrinsik dan penghambatan aktivitas makan.

Regresi probit pada perlakuan dengan metode kontak topikal lebih landai dibandingkan dengan metode pencampuran pada pakan buatan (Tabel 3). Hal ini menunjukkan bahwa peningkatan konsentrasi dengan kelipatan tertentu dengan metode pencampuran pada pakan buatan akan menghasilkan peningkatan kematian serangga uji yang lebih besar. Data tersebut menunjukkan kerja bahan aktif sebagai racun perut (masuk melalui pencernaan) lebih kuat dibandingkan dengan daya kerjanya secara kontak. Hal ini mungkin disebabkan adanya hambatan dari kutikula sehingga tidak semua senyawa aktif berhasil masuk ke dalam darah dan menuju sasaran.

\section{Pengaruh Fraksi Aktif Ekstrak Biji A. harmsiana terhadap Efisiensi Asimilasi Makanan oleh Larva} S. Litura. Secara umum perlakuan fraksi A. harmsiana dengan metode kontak dan metode pencampuran pada pakan buatan pada $\mathrm{LC}_{10}$ dan $\mathrm{LC}_{25}$ menurunkan LP, LPR, EMK, dan EMC jika dibandingkan dengan kontrol, meskipun LKR dan DC pada kedua pengujian tersebut tidak mengalami penurunan (Tabel 4 \& 5). Pada percobaan secara kontak perlakuan dengan fraksi 2-8 pada $\mathrm{LC}_{10}$ dan $\mathrm{LC}_{25}$ menurunkan LK sebesar 21\% dan 24\% (Tabel 4). Hal ini kemungkinan disebabkan bahan aktif biji $A$. harmsiana yang masuk mengikuti peredaran darah menekan aktivitas makan larva uji. Penekanan aktivitas makan tersebut kemungkinan terjadi pada sistem syaraf pusat yang mengatur proses makan. Efek antifeedant sekunder ini memberikan sumbangan terhadap kematian larva meskipun bukan sebagai penyebab utama.

Percobaan dengan metode pencampuran pada pakan buatan menurunkan LP sebesar 33\% dan 67\% meskipun LK tidak terpengaruh (Tabel 5).

Tabel 2. Hasil pemisahan fraksi 2 dari Tabel 1 dan aktivitasnya terhadap larva S. Litura

\begin{tabular}{|c|c|c|c|c|}
\hline Fraksi & $\begin{array}{l}\text { Hasil } \\
(\%)^{1)}\end{array}$ & $\begin{array}{l}\text { Eluen diklorometana-isopropanol } \\
(39: 1)(\mathrm{ml})\end{array}$ & $\mathrm{R}_{\mathrm{f}}$ & $\begin{array}{c}\text { Mortalitas larva } S . \\
\text { litura }(\%)\end{array}$ \\
\hline $2-1$ & 0,0017 & $0-150$ & 0,95 & 5 \\
\hline $2-2$ & 0,0007 & $151-200$ & 0,90 & 15 \\
\hline $2-3$ & 0,0002 & $201-250$ & 0,$85 ; 0,64$ & 5 \\
\hline $2-4$ & 0,0009 & $251-275$ & 0,83 & 5 \\
\hline $2-5$ & 0,0178 & $276-325$ & 0,$85 ; 0,76 ; 0,51$ & 0 \\
\hline $2-6$ & 0,0301 & $326-350$ & 0,$86 ; 0,83 ; 0,68$ & 5 \\
\hline $2-7$ & 0,0184 & $356-375$ & 0,67 & 80 \\
\hline $2-8$ & 0,3773 & $376-875$ & 0,$67 ; 0,47 ; 0,37$ & 100 \\
\hline $2-9$ & 0.0432 & 876-1785 & 0,$5 ; 0,4 ; 0,36 ; 0,25$ & 45 \\
\hline $2-10$ & 0,1386 & Eluen metanol $0-200$ & -(2) & 5 \\
\hline
\end{tabular}


Tabel 3. Parameter regresi probit hubungan konsentrasi fraksi 2-8 ekstrak biji A. harmsiana dengan mortalitas larva S.litura

\begin{tabular}{lccc}
\hline \multicolumn{1}{c}{ Metode } & $\left.\mathrm{b} \pm \mathrm{GB}^{\mathrm{a}}\right)$ & $\mathrm{LC}_{50}(\mathrm{SK} 95 \%)(\%)$ & $\mathrm{LC}_{95}(\mathrm{SK} 95 \%)(\%)$ \\
\hline Kontak topikal & $1,55 \pm 0,34$ & $0,49(0,28-0,66)$ & $5,64(3,10-23,87)$ \\
$\begin{array}{l}\text { Pencampuran ekstrak } \\
\text { pada pakan buatan }\end{array}$ & $3,98 \pm 0,44$ & $0,0044(0,0040-0,0051)$ & $0,0115(0,0091-0,0162)$ \\
\hline \multicolumn{2}{l}{ a) b : kemiringan garis regresi, GB: galat baku, SK: selang kepercayaan }
\end{tabular}

Tabel 4. Pengaruh fraksi 2-8 A. harmsiana terhadap indeks pemanfaatan makanan pada larva S. litura dengan metode kontak

\begin{tabular}{|c|c|c|c|c|c|c|c|c|c|c|c|c|c|}
\hline \multirow[t]{2}{*}{$\begin{array}{c}\text { Konsentrasi } \\
\text { ( } \mu \mathrm{g} / \text { larva) }\end{array}$} & \multicolumn{3}{|c|}{$\begin{array}{l}\text { Laju konsumsi } \\
(\mathrm{mg} / \mathrm{hari})^{1)}\end{array}$} & \multicolumn{4}{|c|}{$\begin{array}{l}\text { Laju pertumbuhan } \\
\text { (mg/hari) })^{1)}\end{array}$} & \multicolumn{6}{|c|}{$\begin{array}{l}\text { Efisiensi pemanfaatan } \\
\text { makanan }(\%)^{1)}\end{array}$} \\
\hline & $\mathrm{LK}^{2)}$ & LKF & & LP & & LP & & $\mathrm{DC}$ & & $\mathrm{EMK}^{2}$ & & $\mathrm{EMC}^{2)}$ & \\
\hline Kontrol & 8,6 & $\begin{array}{ll}\mathrm{a} & 3,9\end{array}$ & $\bar{a}$ & 1,7 & $a$ & 0,8 & $\mathrm{a}$ & 75,4 & $a$ & 20,7 & $a$ & 28 & $a$ \\
\hline $0,00074 / \mathrm{LC}_{10}$ & 6,8 & b 6,3 & b & 0,6 & b & 0,5 & b & 85,6 & b & 9,5 & b & 11,5 & $\mathrm{~b}$ \\
\hline $0,00182 / \mathrm{LC}_{25}$ & 6,5 & b 5,6 & b & 0,8 & b & 0,6 & $\mathrm{~b}$ & 85,7 & $\mathrm{~b}$ & 11,8 & b & 14,1 & $\mathrm{~b}$ \\
\hline
\end{tabular}

1) Angka selajur yang diikuti oleh huruf yang sama tidak berbeda nyata (uji BNT, $\alpha=0,05$ )

2) $\mathrm{LK}=$ laju konsumsi, LKR = laju konsumsi relatif, LP = laju pertumbuhan, LPR = laju pertumbuhan relatif, $\mathrm{DC}$ = daya cerna, $\mathrm{EMK}=$ efisiensi konversi makanan dikonsumsi, dan EMC = efisiensi konversi makanan dicerna

Tabel 5. Pengaruh fraksi 2-8 A. harmsiana terhadap indeks pemanfaatan makanan pada larva S. litura dengan metode pencampuran ekstrak pada pakan buatan

\begin{tabular}{|c|c|c|c|c|c|c|c|c|c|c|c|c|c|c|}
\hline \multirow[t]{2}{*}{ Konsentrasi (\%) } & \multicolumn{4}{|c|}{$\begin{array}{l}\text { Laju konsumsi } \\
\left(\mathrm{mg} / \text { hari }^{1)}\right.\end{array}$} & \multicolumn{4}{|c|}{$\begin{array}{l}\text { Laju pertumbuhan } \\
\left(\mathrm{mg} / \mathrm{hari}^{1)}\right.\end{array}$} & \multicolumn{6}{|c|}{$\begin{array}{l}\text { Efisiensi pemanfaatan } \\
\text { makanan }(\%)^{1)}\end{array}$} \\
\hline & $\mathrm{LK}^{2)}$ & & LKR & & $\mathrm{LP}^{2)}$ & & $\mathrm{LPR}^{2)}$ & & $\mathrm{DC}^{2)}$ & & EMK & & EMC & \\
\hline Kontrol & 2,3 & $\mathrm{a}$ & 3,3 & $\overline{\mathrm{a}}$ & 0,3 & $\mathrm{a}$ & 0,4 & $\overline{\mathrm{a}}$ & 64,4 & $\mathrm{a}$ & 13,0 & $\mathrm{a}$ & 22,4 & $\mathrm{a}$ \\
\hline$\left(0,00283 / \mathrm{LC}_{10}\right)$ & 2,1 & $\mathrm{a}$ & 3,5 & $\mathrm{a}$ & 0,2 & b & 0,3 & $\mathrm{~b}$ & 70,1 & $\mathrm{a}$ & 10,1 & b & 17,3 & $\mathrm{a}$ \\
\hline$\left(0,00368 / \mathrm{LC}_{25}\right)$ & 2,1 & $\mathrm{a}$ & 3,9 & $\mathrm{a}$ & 0,1 & C & 0,2 & C & 81,5 & $\mathrm{~b}$ & 6,5 & C & 8,1 & $\mathrm{~b}$ \\
\hline
\end{tabular}

${ }^{1)}$ Angka selajur yang diikuti oleh huruf yang sama tidak berbeda nyata (uji BNT, $\alpha=0,05$ )

${ }^{2)} \mathrm{LK}=$ laju konsumsi, LKR = laju konsumsi relatif, LP = laju pertumbuhan, LPR = laju pertumbuhan relatif, $\mathrm{DC}=$ daya cerna, EMK = efisiensi konversi makanan dikonsumsi, dan EMC = efisiensi konversi makanan dicerna

Penurunan laju pertumbuhan secara langsung menunjukkan adanya toksisitas intrinsik fraksi 2-8 yang mengganggu fungsi fisiologi serangga, hal ini diperkuat dengan adanya penurunan EMK dan EMC tanpa tergantung nilai LKR dan DC.

Pengaruh Fraksi Aktif Ekstrak Biji A. Harmsiana terhadap Aktivitas Enzim Invertase dan Trehalase Larva $S$. litura. Aktivitas enzim invertase larva uji yang diberi perlakuan fraksi 2-8 pada $\mathrm{LC}_{10}$ dan $\mathrm{LC}_{25}$ menurun masing-masing $34 \%$ dan $47 \%$ jika dibandingkan dengan kontrol (Tabel 6). Hal ini kemungkinan disebabkan oleh toksisitas intrinsik fraksi 2-8, yang menyebabkan gangguan terhadap aktivitas sel epitel di saluran pencernaan yang menyekresi enzim. Senyawa aktif rokaglamida dari ranting dan akar $A$. elliptifolia menghambat aktivitas sel karsinoma epidermoid dari nasofaring manusia (sel KB) pada uji secara in vitro (King et al. 1982). Wang et al. (2001) melaporkan bahwa ekstrak metanol daun A. elliptifolia menghambat sel adenokarsinoma dari paru-paru manusia (A-549), 
Tabel 6. Pengaruh fraksi 2-8 biji A. harmsiana terhadap aktivitas enzim metabolik larva S. litura instar ke-3

\begin{tabular}{llr}
\hline \multirow{2}{*}{\begin{tabular}{c} 
Konsentrasi fraksi \\
\cline { 2 - 3 }
\end{tabular}} & \multicolumn{2}{c}{ Aktivitas enzim (mg glukosa/mg protein) $^{\mathrm{a}}$} \\
\cline { 2 - 4 } 0/kontrol & $1,426 \mathrm{a}$ & Trehalase $^{\mathrm{b}}$ \\
$0,00283 / \mathrm{LC}_{10}$ & $0,948 \mathrm{~b}$ & 0,561 a \\
$0,00368 / \mathrm{LC}_{25}$ & $0,762 \mathrm{~b}$ & 0,596 a \\
\hline
\end{tabular}

${ }^{\mathrm{a}}$ Lama reaksi 60 menit.

${ }^{\mathrm{b}}$ Angka selajur yang diikuti oleh huruf yang sama tidak berbeda nyata (uji BNT, $\alpha=0,05$ )

aenokarsinoma dari pencernaan manusia (HT-29) dan sel leukemia dari limfa tikus (P-388).

Pada pengujian enzim trehalase tidak terjadi peningkatan yang nyata pada setiap perlakuan (Tabel 6). Kemungkinan penurunan glukosa yang diserap akibat penurunan aktivitas enzim invertase dalam saluran pencernaan masih dapat ditoleransi sehingga pelepasan enzim trehalase yang mengubah trehalose dalam darah menjadi dua molekul glukosa sebagai kompensasi penurunan glukosa yang diserap belum terlalu tinggi.

Hasil pengujian di atas menunjukkan bahwa fraksi aktif biji $A$. harmsiana menunjukkan aktivitas insektisida yang kuat terhadap larva S. litura. Selain menyebabkan kematian juga menghambat pertumbuhan larva uji. Kematian larva disebabkan adanya toksisitas intrinsik dan efek antifeedant. Toksisitas intrinsik tersebut dapat menghambat aktivitas makan serangga melalui penekanan syaraf pusat yang mengatur aktivitas makan (antifeedant sekunder) selain itu juga menekan aktivitas enzim pencernaan yaitu enzim invertase. Penurunan enzim invertase ini proporsional dengan penambahan konsentrasi. Gangguan di atas secara keseluruhan dapat menghambat pertumbuhan serangga dan mengakibatkan kematian serangga.

\section{SIMPULAN}

Fraksi aktif ekstrak biji A. harmsiana memiliki aktivitas insektisida yang kuat terhadap larva $S$. litura. Selain toksik fraksi tersebut juga bersifat antifeedant sekunder, sehingga menghambat aktivitas makan dan pertumbuhan larva. Komponen aktif ekstrak A. harmsiana secara langsung juga mempengaruhi fisiologi serangga sehingga terjadi penurunan enzim pencernaan yang menghambat konversi makanan yang dimakan menjadi biomassa. Penelitian lebih lanjut perlu dilakukan untuk mengisolasi dan mengidentifikasi senyawa aktif serta mengetahui cara kerja komponen ekstrak pada tingkat biokimia serangga.

\section{SANWACANA}

Dana penelitian diperoleh dari proyek Riset Unggulan Terpadu (RUT) VIII atas nama Dr. Bambang Wahyu Nugroho (Alm).

\section{DAFTAR PUSTAKA}

Coll, J.C. \& B.F. Bowden. 1986. The application of vacuum liquid chromatography to the separation of terpene mixtures. J. Nat. Prod. 49: 934-936.

Dono, D, D. Prijono, S. Manuwoto \& D. Buchori. 1998. Pengaruh ekstrak biji Aglaia harmsiana Perkins (Meliaceae) terhadap interaksi antara Crocidolomia binotalis Zeller (Lepidoptera: Pyralidae) dan parasitoidnya, Eriborus argenteopilosus (Cameron) (Hymenoptera: Ichneumonidae). Bul. HPT 10: 38-46.

Finney, D.J. 1971. Probit Analysis. Ed ke-3. Cambridge: The University Press.

Hartati, S \& D. Prijono. 1994. Aglaia harmsiana Perkin (Meliaceae): a potential source of insect antifeedant and growth regulator. Bul. HPT 1:75-76.

Ishaaya, I., A. Hirashima, S. Yablonski, S. Tawata \& M. Eto. 1990. Mimosine, a nonprotein amino acid, inhibits growth and enzyme system in Tribolium castaneum. Pestic. Biochem. Physiol. 39: 35-42.

Isman, M.B. 1995. Leads and prospects for the development of new botanical insecticides. Rev. Pestic. Toxicol. 3:1-20. 
King, E.G. \& G.G. Hartley. 1985. Heliothis virescens. Pages 323-328 in: Singh P, R.f. Moore, ed. Handbook of Insect Rearing. Vol ke-2. Amsterdam: Elsevier.

King, M.L., C.C. Chiang, H.C. Ling, E. Fujita \& M. Ochiai M. 1982. X-ray crystal structure of rocaglamide, a novel antileukemic $1 H$ cyclopenta $[b]$ benzofuran from Aglaia elliptifolia. J Chem Soc Chem Commun 446:1150-1151.

Kresze, G. 1998. Methods for protein determination. Pages 84-99 in: Bergmeyer HU, J.. Bergmeyer, ed. Methods of Enzymatic Analysis. Ed ke-3. Weinheim:VCH. hlm 84-99.

Kuroki, T. 1998. Cancers as a disease of genes and a disease due to environmental factors. Pages 113-118 in: Kuhr RJ, N. Motoyama N, ed. Pesticides and the Future; Minimizing Chronic Exposure of Humans and the Environment. Washington: IOS Press.

Metcalf, R.L. 1982. Insecticides in pest management. Pages 217-253 in: Metcalf RL, W.H. Luckman, ed. Introduction to Insect Pest Management. New York: J Wiley.
Nugroho, B.W., B. Güssregen, V. Wray, L. Witte, G. Bringmann \& P. Proksch. 1997. Insecticidal rocaglamide derivatives from Aglaia elliptica and Aglaia harmsiana (Meliaceae). Phytochemistry 45:1579-1585.

Satasook, C., M.B. Isman, F. Ishibashi, S. Medbury, P. Wiriyachitra \& G.H.N. Towers. 1994. Insecticidal bioactivity of crude extracts of Aglaia species (Meliaceae). Biochem System Ecol 22:121-127.

Schmutterer, H., editor. 1995. The Neem Tree Azadirachta indica A. Juss, and Other Meliaceous Plants: Sources of Unique Natural Products for Integrated Pest Management, Medicine, Industry and Other Purposes. Weinheim: VCH.

Steel, R.G.D. \& J.H. Torrie. 1980. Principles and Procedures of Statistics: A Biometrical Approach. Ed ke-2. New York: McGraw-Hill.

Wang, S.K., Y.J. Cheng \& C.Y. Duh. 2001. Cytotoxic constituents from leaves of Aglaia elliptifolia. J Nat Prod 64: 92-94.

Wiyantono, D. Prijono \& S. Manuwoto. 2001. Bioaktivitas ekstrak biji Aglaia harmsiana terhadap ulat krop kubis, Crocidolomia binotalis. J. Ilmu. Pert. Indon. 10(1):1-7. 